\title{
Petrophysical Features of Lava Flows from Bezymyannyi Volcano, Kamchatka
}

\author{
V. M. Ladygin ${ }^{a}$, O. A. Girina ${ }^{b}$, and Yu. V. Frolova ${ }^{a}$ \\ ${ }^{a}$ Faculty of Geology, Moscow State University, 119992 Russia \\ e-mail: skalka_1@mail.ru \\ ${ }^{b}$ Institute of Volcanology and Seismology, Far East Branch, Russian Academy of Sciences, \\ bul'var Piipa 9, Petropavlovsk-Kamchatskii, 683006 Russia
}

Received January 16, 2012

\begin{abstract}
This paper presents results from a study of lava flows that were discharged by Bezymyannyi Volcano at different times, from old (about 3500 years ago) to recent ones (1985-1989). We provide detailed descriptions of the composition, structure, and petrophysical properties for the main types of constituent rocks, which are andesites and basaltic andesites. It was found that porosity is the leading factor that controls rock properties, while the effects of structural and mineralogical features are less prominent. We demonstrate the variation in the properties of rocks that compose the lava flows in relation to their ages: the older a rock is, the higher its density and strength and the lower its porosity is.
\end{abstract}

DOI: $10.1134 / \mathrm{S} 074204631206005 \mathrm{X}$

\section{INTRODUCTION}

The petrophysical properties of rocks bear the full imprint of their generation conditions and of all subsequent transformations since the time of generation; these include the character and composition of the primary magma, the amount of fluids in the melt, the variety of minerals that compose the rock, their initiation and growth, which depend on the temperature and pressure; the shape and character of mineral intergrowth, and so on. These same issues are of interest to geologists and volcanologists. For this reason, the information that can be gathered from petrophysical studies may provide insights into the generation of a rock, its age, the character of the eruption that created it, etc. [see, e.g., Alypova, 1967; Girina, 1998; Ladygin and Nikitin, 1980; Ladygin and Okrugin, 1998; Ladygin and Frolova, 2002, 2006; Kozyrev et al., 1989; Kozyrev, 1990].

We know that the most typical volcanoes of Kamchatka are of two types, basaltic (e.g., Klyuchevskoi and Tolbachik) and basaltic andesite-andesitic ones (e.g., Bezymyannyi, Avacha, and Mutnovskii). While there are extensive data concerning the petrophysical properties of rocks that compose the basaltic volcanoes [see, e.g., Alypova, 1967; Ladygin and Nikitin, 1980; Kozyrev, 1990; Ladygin and Okrugin, 1998; Ladygin and Frolova, 2002], the data on andesitic volcanoes are scarce [see, e.g., Alypova, 1967; Girina, 1998; Kozyrev et al., 1989; Ladygin et al., 2004]. The present authors possess rock samples from all the three andesitic volcanoes mentioned above (of different ages) and we envisage a future comparative analysis of their petrophysical properties. The first paper from this series is devoted to the effusive rocks that have been discharged by Bezymyannyi Volcano.

Bezymyannyi is situated on the slope of the older Kamen' Volcano in the middle of the Klyuchevskoi volcanic cluster. The absolute altitude of this volcano had been $3085 \mathrm{~m}$ prior to the paroxysmal eruption of 1956 , at present it is about $2900 \mathrm{~m}$. The age of Bezymyannyi proper is about 5500 years, while that of Pra-Bezymyannyi (Older Bezymyannyi) is 10500-11000 years [Braitseva, 1990; Bogoyavlenskaya et al., 1991]. The 1956 eruption made Bezymyannyi one of the best known volcanoes in the world. Numerous publications have dealt with various aspects of both the 1956 and later eruptions [Gorshkov and Bogoyavlenskaya, 1963; Bogoyavlenskaya and Kirsanov, 1981; Braitseva, 1990; Kirsanov, 1979; Maksimov et al., 1991; Tolstykh et al., 1999, to name a few]. These works discussed issues in eruption dynamics, the history of the volcano, the study of the structure and composition of lavas, but little attention was allotted to petrophysical features of the rocks that were generated by these processes; in our opinion, this detracts from the value of available information on the activity of the volcano. The present paper is the first to report on the properties of effusive rocks that were discharged by Bezymyannyi, whose generation and later transformation took place between 3500 B.P. and 1985-1989.

The volcano consists of two parts, an (older) eastern part and a western part, which is younger. The volcano's structure is dominated by an old extrusive dome whose remains could be observed on the south and north walls 


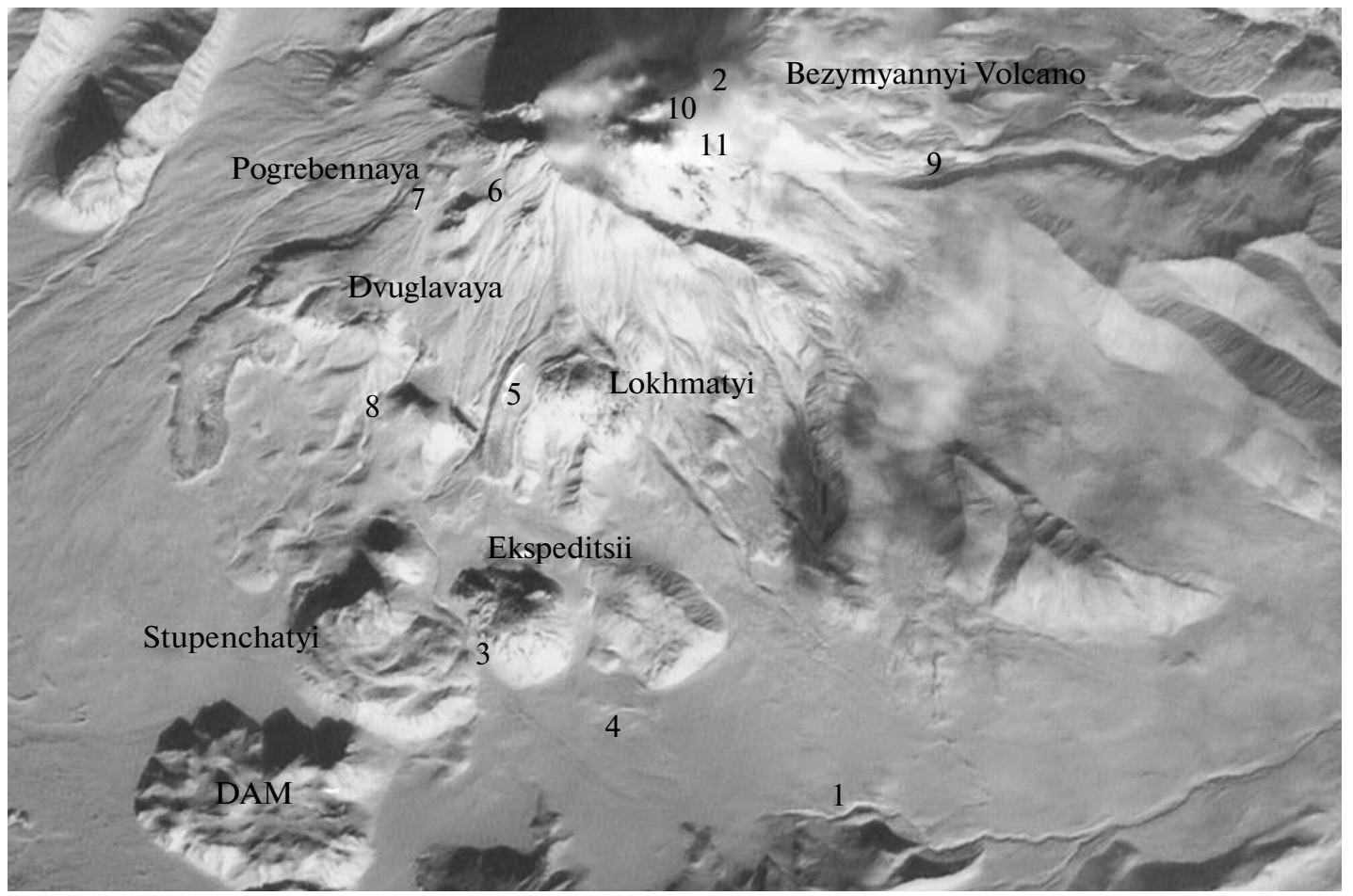

Fig. 1. A map that shows the lava flows of Bezymyannyi Volcano that were studied in this paper.

(1) oldest flows in Tundrovyi Brook, (2) on the northeastern side of the 1956 explosion crater, (3) between the Ekspeditsii and Stupenchataya extrusions, (4) south of the Booth of Volcanologists, (5) between the Pestrye Khrebtiki and Lokhmatyi extrusive domes, (6) under the Vysokaya extrusion, (7) near the Pogrebennaya extrusion, (8) between the Dvuglavaya and Gladkaya extrusions, (9) in the ravine between Bezymyannyi and Kamen' volcanoes, (10) on the Novyi dome (1981-1983), (11) on the Novyi dome (19851989). This map is based on the ASTER satellite image taken on January 23, 2005.

of the explosion crater that formed in 1956. The dome was composed of coarse clastic rocks penetrated by dikes. The western part of the volcano is a typical stratovolcano.

The volcano has shown pulsating activity [Braitseva and Kirsanov, 1982; Braitseva et al., 1990]. Each active period showed a pattern in the composition of the volcanic rocks, changing from acidic varieties to more basic ones and back to more acidic varieties again.

\section{LAVA FLOWS OF BEZYMYANNYI VOLCANO}

Bezymyannyi is a unique geological feature, considering that the sufficiently long history of this volcano's evolution produced different facies of magmatic formations: extrusive domes, lava and pyroclastic flows. The complex evolution of magma melts that led to the generation of rocks on Bezymyannyi has been mentioned by several authors [Bogoyavlenskaya et al., 2004; Kadik et al., 1986; Ozerov et al., 1997; Tolstykh et al., 1999; Almeev et al., 2004].

Being a stratovolcano, the Bezymyannyi cone is composed of numerous lava flows that alternate with interbeds of clastic volcanogenic rocks. The best exposures of lava flows can be found in the northern, southern, and southeastern parts of the volcano's edifice. The longest and thickest lava flows occur on the southern and southwestern slopes (Fig. 1). In addition, lava flows have been almost annually discharged since 1977 to build a lava dome within the 1956 explosion crater; these lava flows terminated the explosive phases of eruptions that contributed to the growth of the lava dome [Bogoyavlenskaya and Kirsanov, 1981; Girina and Gorbach, 2006; Malyshev, 2000, among others].

O.A. Braitseva et al. [1990] identified three active periods of Bezymyannyi for the last 2500 years (B-I, B-II, and B-III) and six age groups of lava flows (I, II, III, IV, V, and VI).

(1) Lava flows of age group I (about 3500 B.P.), bipyroxene basaltic andesites.

(2) Volcanic rocks that formed during active period B-I (2400-1700 B.P.):

(a) Lava flows of age group II (bipyroxene basaltic andesites); ites).

(b) Lava flows of age group III (bipyroxene andes-

(3) Volcanic rocks that formed during active period B-II (1350-1000 B.P.): ites);

(a) Lava flows of age group IV (bipyroxene andes-

(b) Lava flows of age group V (hornblende pyroxene andesites). 
Table 1. The chemical composition of Bezymyannyi lavas in age groups I through V after [Braitseva et al., 1990]

\begin{tabular}{l|c|c|c|c|c|c|c|c|c|c|c}
\hline Lavas & $\mathrm{SiO}_{2}$ & $\mathrm{TiO}_{2}$ & $\mathrm{Al}_{2} \mathrm{O}_{3}$ & $\mathrm{Fe}_{2} \mathrm{O}_{3}$ & $\mathrm{FeO}$ & $\mathrm{MnO}$ & $\mathrm{MgO}$ & $\mathrm{CaO}$ & $\mathrm{Na}_{2} \mathrm{O}$ & $\mathrm{K}_{2} \mathrm{O}^{2}$ & $\mathrm{P}_{2} \mathrm{O}_{5}$ \\
\hline $\mathrm{V}$ & $58.0-60.4$ & $0.5-0.8$ & $17.4-18.2$ & $2.2-2.6$ & $3.5-4.6$ & 0.1 & $3.0-4.1$ & $6.8-7.4$ & $3.2-3.6$ & $1.3-1.8$ & 0.2 \\
$\mathrm{IV}$ & $57.6-58.2$ & 0.6 & $17.4-17.7$ & $1.9-2.3$ & $4.0-4.6$ & 0.15 & $4.9-5.3$ & 6.8 & $3.3-3.5$ & $1.5-1.6$ & 0.25 \\
$\mathrm{III}$ & $59.0-59.2$ & 0.7 & 17.2 & $2-2.5$ & $3.5-4.4$ & 0.16 & $3.9-4.4$ & $6.9-7.1$ & $3.4-3.5$ & $1.5-1.6$ & 0.25 \\
$\mathrm{II}$ & $54.3-57.0$ & $0.5-1.0$ & $17.1-18.7$ & $2.1-3.1$ & $4.0-6.0$ & $0.1-0.2$ & $4.1-5.2$ & $7.7-8.8$ & $3.0-3.1$ & $1.1-1.6$ & 0.28 \\
$\mathrm{I}$ & 54.4 & 0.8 & 17.4 & 2.7 & 5.7 & 0.15 & 5.6 & 8.8 & 3.0 & 1.2 & 0.18 \\
\hline
\end{tabular}

(4) Volcanic rocks that formed during the B-III active period (1955 to present); these are lava flows of age group VI (hornblende pyroxene andesites).

The rocks produced by Bezymyannyi stratovolcano proper during the first phase of its activity have compositions that are consistent with basaltic andesites with $\mathrm{SiO}_{2}$ between 54 and $57 \mathrm{wt} \%$.

The volcanic rocks of the B-I period include a wide range of effusive rocks from basaltic andesites to andesites with concentrations of $\mathrm{SiO}_{2}$ from 54.3 to $59.2 \mathrm{wt} \%$ (Table 1). The B-II rocks have compositions that are consistent with andesites, with the concentrations of $\mathrm{SiO}_{2}$ ranging from 57.6 to $60.4 \mathrm{wt} \%$. The lavas of the recent phase B-III have compositions that vary from the 1956 andesites $\left(59-60 \mathrm{wt} \%\right.$ of $\left.\mathrm{SiO}_{2}\right)$ to basaltic andesites (56-58 wt \%) [Braitseva et al., 1990].

A lava flow is understood to be a volcanic feature with pronounced geometric shapes, viz., length is the dominant dimension compared with width and thickness. Lava flows were sampled in the southeastern and northern parts of the volcano, as well as near the following extrusive domes: Ekspeditsii, Stupenchataya, Lokhmatyi, Vysokaya, Pogrebennaya, Dvuglavaya, and Gladkaya. A total of 113 lava samples were studied. We obtained data on the chemical composition of the rocks; we determined their physical and physicomechanical properties as well: density $(\rho)$, density of the solid phase $\left(\rho_{0}\right)$, porosity $(n)$, water absorption $(W)$, compressional velocity in dry (Vpd) and water-saturated (Vpw) state of the rock, magnetic susceptibility $(æ)$, compressive strength in dry (Rs) and water-saturated (Rsw) state.

The rocks of lava flows that were sampled for further study were rather difficult to classify as being due to specified periods of volcanic activity, because it is not always possible in the field to find and classify tephra maker horizons after [Braitseva et al., 1990]. In most cases the marker of lava flows was an extrusive feature (see Fig. 1); for this reason the effusive rocks are described following the order that is indicated in Table 2.

\section{LAVA FLOWS OF AGE GROUP I-V}

(1) We definitely identified the oldest rocks (lavas of age I), which compose lava flows from 2 to 5-7 $\mathrm{m}$ thick at the brink of Tundrovyi Brook (see Table 2 and Fig. 1). These rocks are mostly basaltic andesites with concentrations of $\mathrm{SiO}_{2}$ that are equal to $54.5 \%$, are dark grey in color with numerous (up to $20-40 \%$ ) serial porphyry phenocrysts (from 0.3 to $1.5 \mathrm{~mm}$ across) that consist of plagioclase and pyroxene, with the latter being less numerous. Most plagioclase crystals contain zones that are enriched in inclusions of volcanic glass. The basaltic andesites occasionally contain small olivine crystals. The groundmass texture varies, ranging from intersertal to hyalopilitic. The groundmass is composed of plagioclase microlites that are less than $0.1 \mathrm{~mm}$ across and are usually elongate in shape; isometric pyroxene crystals with light-colored glass found in the interspaces between the crystals are considerably less numerous. The ore minerals include titanomagnetite, which is found in the form of small (less than $0.05 \mathrm{~mm}$ ) crystals or as fine ore dust.

The effusive rocks have higher values of physicomechanical properties (Table 3). They are dense rocks with low porosity (below 10\%), high strength, low values of $\mathrm{V}_{\mathrm{p}}$ (mostly below $3 \mathrm{~km} / \mathrm{s}$ ) in the dry state and higher values when saturated with water. We note that higher values of magnetic susceptibility occur in rocks where the ore mineral is in the form of fine dust rather than as individual crystals. The rocks at the top of lava flows (B-1g) are more porous with a hyalopilitic groundmass texture.

(2) Several lava flows of Bezymyannyi stratovolcano proper were sampled inside the 1956 explosion crater where the Novyi dome is at present growing, in its northeastern wall (see Table 2 and Fig. 1). These lava flows are rather diverse. They are mostly composed of basaltic andesites consisting of porphyry varieties with phenocrysts of plagioclase $(20-30 \%)$ and of pyroxene (15-25\%), both rhombic and monoclinic (the latter are more numerous). Most phenocrysts are up to 0.5$1 \mathrm{~mm}$ across, with larger crystals (up to $3 \mathrm{~mm}$ ) being rare. The plagioclase contains many zones with volcanic glass. The groundmass is diverse and has differing textures: microophitic, intersertal, and hyalopilitic; the 
Table 2. Lava flows around Bezymyannyi Volcano

\begin{tabular}{|c|c|c|c|}
\hline \# & Sample \# & Locality & Rock \\
\hline 1 & B-1 $(a-g)$ & Tundrovyi Brook & Pyroxene basaltic andesites \\
\hline 2 & $\begin{array}{l}831011(1-14) \\
\text { B-14 (a, b, c) }\end{array}$ & $\begin{array}{l}\text { northeast wall of the } 1956 \text { explosion crater on Bezymy- } \\
\text { annyi Volcano }\end{array}$ & $\begin{array}{l}\text { (two flows only, containing hornblende } \\
\text { andesites) }\end{array}$ \\
\hline 3 & $\mathrm{~B}-2(\mathrm{a}, \mathrm{b}, \mathrm{c})$ & between Ekspeditsii and Stupenchataya extrusions & hornblende andesite \\
\hline 4 & $\mathrm{~B}-18(\mathrm{a}, \mathrm{b}, \mathrm{c}, \mathrm{d})$ & south of the Booth of Volcanologists & hornblende andesite \\
\hline 5 & B-19 & between Pestrye Khrebtiki and Lokhmatyi extrusions & hornblende andesite \\
\hline 6 & $\mathrm{~B}-23(\mathrm{a}, \mathrm{b}, \mathrm{c}, \mathrm{d})$ & Under Vysokaya extrusion & hornblende andesite \\
\hline 7 & $\mathrm{~B}-25(\mathrm{a}, \mathrm{b}, \mathrm{c}, \mathrm{d}, \mathrm{e})$ & Near Pogrebennaya extrusion & hornblende andesite \\
\hline 8 & $\mathrm{~B}-27(\mathrm{a}, \mathrm{b}, \mathrm{c}, \mathrm{d}, \mathrm{e}, \mathrm{f})$ & Between Dvuglavaya and Gladkaya extrusions & aphyric andesite \\
\hline 9 & $\begin{array}{l}\text { B-34 }(\mathrm{a}, \mathrm{b}, \mathrm{c}) \\
\mathrm{B}-35 \mathrm{~B}-36\end{array}$ & $\begin{array}{l}\text { The ravine between Bezymyannyi and Kamen' volca- } \\
\text { noes }\end{array}$ & Pyroxene basaltic andesites \\
\hline
\end{tabular}

groundmass is mostly composed of microlites of plagioclase (less than $0.1 \mathrm{~mm}$ across) and of pyroxene (up to $0.5 \mathrm{~mm}$ ) and of volcanic glass in varying ratios.

Among these rocks andesites with hornblende phenocrysts and a microlite texture of the groundmass stand out (see Table 3); these andesites have unusually low values of $V_{p}$, even when compared with the other effusive rocks.

(3) Effusive rocks between the Ekspeditsii and Stupenchataya extrusions (see Table 2 and Fig. 1). We sampled one flow that was $3 \mathrm{~m}$ thick with a clearly visible bottom and top. The flow is composed of dark-grey basaltic andesites, with large numbers of serial porphyry phenocrysts of plagioclase and pyroxene (from 0.3 to $1.5 \mathrm{~mm}$ across) and with glomeroporphyritic intergrowths of monoclinic pyroxene that have the same size. Rhombic pyroxenes below $1 \mathrm{~mm}$ across are less numerous. The groundmass texture is intersertal microophitic and is composed of plagioclase microlites, pyroxene crystals (both monoclinic and rhombic) and an insignificant amount of volcanic glass (less than $10 \%$ ). Nearly the entire flow consists of massive varieties; porous varieties as thick as $0.2-0.4 \mathrm{~m}$ are found only in its upper part. The pores are small and irregular in shape, no larger than $1 \mathrm{~mm}$ across, and are distributed throughout the rock volume fairly uniformly. In places where the flow thins down to $0.7 \mathrm{~m}$, the rock becomes more porous and acquires hyalopilitic texture because of a great amount of brown volcanic glass. All rock properties vary in accordance with a transition from massive to porous varieties (see Table 3 ).
(4) Effusive rocks south of the Booth of Volcanologists (see Table 2 and Fig. 1). The flow is composed of dark grey porphyry basaltic andesites, which are porous for the most part and occasionally massive. There are porphyry phenocrysts of two kinds: large plagioclase ones, as large as $1.5 \mathrm{~mm}$ across, with inclusions of volcanic glass, and smaller ones, within $0.5 \mathrm{~mm}$, consisting of plagioclase and monoclinic and rhombic pyroxene (the latter are considerably less abundant). Phenocrysts are up to $15-20 \%$ of the rock. The groundmass has a hyalopilitic texture. The volcanic glass is brown with immersed microlites of plagioclase and, to a lesser degree, of pyroxene. The ore minerals are few. The values of the properties also decrease as one goes from massive to porous rocks (see Table 3).

(5) Effusive rocks between the Pestrye Khrebtiki and Lokhmatyi extrusive domes (see Table 2 and Fig. 1). The basaltic andesites are dark grey, similar to the lavas near the Booth of Volcanologists that were described above. The properties are similar as well, being only different in having higher densities (see Table 3).

(6) Effusive rocks under the Vysokaya extrusion (see Table 2 and Fig. 1). The andesites are grey and red, with similar porphyry textures. The phenocrysts are between 0.5 and $1.5 \mathrm{~mm}$ across and consist of plagioclase and orange hornblende crystals. The groundmass in the most porous varieties is composed of plagioclase and small hornblende crystals. All the microlites are below $0.05 \mathrm{~mm}$ across. The main texture element is light-colored volcanic glass, which creates the hyalopilitic texture. The andesites with hornblende have low density and compressional velocity compared with the other rocks we considered (see Table 3). 
(7) Effusive rocks near the Pogrebennaya extrusion (see Table 2 and Fig. 1). The andesites are dark grey and porous; no massive varieties can be detected by the naked eye. The porphyry phenocrysts between 0.5 and $1.5 \mathrm{~mm}$ across consist of plagioclase, hornblende, and monoclinic pyroxene, with the amounts of plagioclase and hornblende being approximately equal. The phenocrysts amount to $30-40 \%$ of the rock. The groundmass is composed of plagioclase microlites, volcanic glass, and occasional, small, hornblende crystals. The groundmass texture is intersertal and hyalopilitic. The rocks typically have average values of density and strength and low compressional velocities (see Table 3 ).

(8) Effusive rocks between the Dvuglavaya and Gladkaya extrusions (see Table 2 and Fig. 1). The basaltic andesites are grey, greenish, and dark grey, with platy parting, have a massive habit, no porous varieties were found. The rocks have an aphyric texture. Occasional plagioclase crystals as small as $1 \mathrm{~mm}$ across and still smaller, even $0.3 \mathrm{~mm}$, occur. The groundmass is composed of long, extended plagioclase microlites with extended small crystals of monoclinic pyroxene among them, with the length of these microlites being less than $0.08 \mathrm{~mm}$. The amount of these in the groundmass does not exceed $25-30 \%$. The groundmass texture is intersertal microophitic. The physicomechanical properties of these basaltic andesites have the highest parameters among all the other Bezymyannyi lava flows (see Table 3).

(9) Effusive rocks in the ravine between Bezymyannyi and Kamen' volcanoes (see Table 2 and Fig. 1). The basaltic andesites are dark grey with a porphyry texture. The phenocrysts are large (up to $2 \mathrm{~mm}$ across) plagioclase crystals (zonal, with glass inclusions) and smaller (within $1 \mathrm{~mm}$ ) crystals of monoclinic and rhombic pyroxenes, with the former forming glomerophyric intergrowths as large as $2 \mathrm{~mm}$ across. The groundmass has a hyalopilitic texture, with brown glass containing microlites and crystallites of plagioclase, as well as of pyroxene and ore minerals, although in much smaller amounts. The rocks have properties that are similar to those for the lava flows near the Pogrebennaya extrusion (see Table 3).

\section{THE LAVA FLOWS OF AGE GROUP VI (1955 TO PRESENT)}

The evolution of Bezymyannyi Volcano during the first 20 years (1956-1976) consisted in squeezing out plastic and rigid domes in the 1956 explosion crater; the growth of these domes was accompanied by powerful explosions that produced ash-block pyroclastic flows [Kirsanov, 1979]. No effusion of lava flows took place during that time.

The appearance of the first viscous lava flow on the dome was first observed in February 1977 [Bogoyavlenskaya and Kirsanov, 1981]. That time ushered in a new phase in the volcano's activity that lasted until the present. The distinguishing feature of this period is the clear-cut phasal nature in the evolution of an eruption: a slow forcing out of a block of viscous lava on top of the dome, ash explosions of varying intensities, a minor directional explosion, the generation of pyroclastic flows, the forcing out of a viscous lava flow on to the slope of the volcano's dome [Ladygin et al., 2004]. The rate at which lava flows were generated on the dome slope varied between $3-4 \mathrm{~cm} / \mathrm{h}$ (November 1981) and $10 \mathrm{~m} / \mathrm{h}$ (June 1986), with the thickness of one flow reaching 20-25 m [Malyshev, 2000].

In 1981-1983 three small viscous lava flows were squeezed out on the slope of Novyi dome; the flows consisted of dark grey fine-porous andesite as thick as 4-7 $\mathrm{m}$. The andesites had a porphyry texture, the phenocrysts were $5-15 \%$ of total volume and were composed of plagioclase as large as $0.5-2.0 \mathrm{~mm}$ across. Glomerophyric bodies were rare. The groundmass was composed of plagioclase microlites 0.05 to $0.3 \mathrm{~mm}$ across, as well as of crystals of monoclinic and rhombic pyroxene of about the same size. The rhombic pyroxene in the 1983 andesites was mostly oxidized. The groundmass texture was intersertal, volcanic glass (white, transparent, with numerous crystallites) was $15-20 \%$ of rock volume. The andesites were highly porous (up to $21-35 \%$ ), with the highest values of porosity being observed in the top of the flows (specimens designated a) (see Table 3). Even though the porosity varied, the compressional velocities were very low, mostly below $2 \mathrm{~km} / \mathrm{s}$, with this parameter noticeably increasing when the andesites were saturated with water. The 1981 andesites have a magnetic susceptibility that considerably decreases toward the upper parts of the flows (see Table 3).

Following the Bezymyannyi eruption of June 30July 1, 1985, the largest since the 1956 disaster, the destroyed sector of the dome began to be filled with lava flows [Alidibirov et al., 1988]. The process continued until 1989, although two moderately large explosive eruptions occurred on the volcano in 1986 during the discharge of lava [Maksimov et al., 1991; Malyshev, 2000]. The lava flow was moving down the dome slope at an average rate of 5-8 m/h after the July 1986 eruption. The flow had moved about 500-550 $\mathrm{m}$ down the slope and its thickness was estimated to be $10 \mathrm{~m}$; hence, the area was $0.3 \cdot 10^{6} \mathrm{~m}^{2}$ and the volume was $3 \cdot 10^{6} \mathrm{~m}^{3}$ [Malyshev, 2000]. At first sight the flow appeared to be a single squeezing-out of viscous lava with a scaly surface, its body was covered with transverse tension fissures. The southern part of the flow contained a vertical fissure that gaped a few meters toward the flow surface. In this fissure one could observe a gradual transition from denser inner parts of the flow to a foamy edge zone. Several andesite zones have been identified from deep in the flow toward the surface: very dense lightcolored andesite, less dense dark grey to black andesite, and foamy greenish-grey andesite that composed the top surface of the flow [Ladygin et al., 2004]. A consecutive series of rock samples from this fissure was collected by O.A. Girina during field work on Bezymyan- 
Table 3. The physicomechanical properties of rocks in the Bezymyannyi lava flows

\begin{tabular}{|c|c|c|c|c|c|c|c|c|c|}
\hline Sample \# & $\rho \mathrm{g} / \mathrm{cm}^{3}$ & $\rho_{0} \mathrm{~g} / \mathrm{cm}^{3}$ & $n \%$ & $W \%$ & Vpd km/s & Vpw km/s & Rs MPa & Rsb MPa & $\not \mathfrak{x} \cdot 10^{-3}$ SI units \\
\hline 1 & 2 & 3 & 4 & 5 & 6 & 7 & 8 & 9 & 10 \\
\hline \multicolumn{10}{|c|}{ in Tundrovyi Brook } \\
\hline B-1 a & 2.6 & 2.91 & 8.5 & 1.8 & 2.3 & 3.7 & 142 & - & 25.4 \\
\hline B-1 b & 2.58 & 2.91 & 9.2 & 0.8 & 3.2 & 4.8 & 168 & 104 & 87 \\
\hline B-1 c & 2.63 & 2.91 & 7.4 & 0.9 & 2.5 & 4.4 & 157 & - & 53.1 \\
\hline B-1 d & 2.65 & 2.91 & 6.7 & 1.4 & 3.7 & 4.7 & 195 & 147 & 57.7 \\
\hline B-1 e & 2.73 & 2.91 & 3.9 & 0.8 & 2.7 & 4.4 & 214 & 118 & 29.7 \\
\hline B-1 h & 2.68 & 2.91 & 5.6 & 1.1 & 2.75 & 4.35 & 221 & 172 & 29 \\
\hline Mean & 2.65 & 2.91 & 6.8 & 1.1 & 2.85 & 4.4 & 183 & - & 46 \\
\hline B-1 g & 2.22 & 2.91 & 21.8 & 2.3 & 2.3 & 4.35 & 53 & 52 & 14.2 \\
\hline \multicolumn{10}{|c|}{ in northeastern wall of the 1956 explosion crater on Bezymyannyi Volcano } \\
\hline $831011-2$ & 2.46 & 2.82 & 12.8 & 1.5 & 3.75 & 4.25 & 99 & 99 & 8.5 \\
\hline $831011-3$ & 2.63 & 2.82 & 6.7 & 0.7 & 4.3 & 5.0 & 163 & - & 6.0 \\
\hline $831011-3$ a & 2.51 & 2.82 & 11.0 & 0.9 & 3.1 & 4.5 & 114 & 96 & 0.0 \\
\hline $831011-4$ & 2.66 & 2.83 & 6.0 & 1.1 & 4.4 & 5.0 & 192 & 154 & 8.0 \\
\hline $831011-5$ & 2.18 & 2.79 & 21.9 & 4.8 & 2.5 & 4.0 & 70 & 59 & 3.1 \\
\hline $831011-5$ a & 2.15 & 2.79 & 22.9 & 7.6 & 2.3 & 3.75 & 60 & 56 & 3.0 \\
\hline $831011-6$ & 2.71 & 2.8 & 3.2 & 1.1 & 3.25 & 4.1 & 207 & 191 & 7.0 \\
\hline $831011-7$ & 2.57 & 2.8 & 8.2 & 1.2 & 2.7 & 4.25 & 125 & 76 & 4.5 \\
\hline $831011-8$ & 2.56 & 2.82 & 9.2 & 1.2 & 2.8 & 3.95 & 135 & - & 6.7 \\
\hline 831011-9 & 2.49 & 2.81 & 11.4 & 0.9 & 2.75 & 4.3 & 88 & 85 & 8.0 \\
\hline $831011-10$ & 2.5 & 2.75 & 9.1 & 1.9 & 2.35 & 3.55 & 95 & 83 & 7.3 \\
\hline 831011-11 & 2.6 & 2.83 & 9.9 & 1.4 & 3.45 & 4.05 & 110 & - & 7.3 \\
\hline 831011-14 & 2.65 & 2.82 & 6.0 & 1.1 & 3.4 & 4.05 & 182 & 182 & 8.7 \\
\hline 831011-15 & 2.47 & 2.74 & 9.9 & 3.3 & 1.8 & 2.45 & 127 & 117 & 9.8 \\
\hline 831011-16 & 2.45 & 2.74 & 10.6 & 3.8 & 1.85 & 2.55 & 91 & 84 & 2.0 \\
\hline B-14 a & 2.64 & 2.8 & 5.7 & 1.3 & 2.2 & 3.9 & 161 & 102 & 10.6 \\
\hline B-14 b & 2.43 & 2.8 & 13.2 & 1.5 & 2.6 & 4.1 & 107 & 96 & 8.0 \\
\hline B-14 c & 2.2 & 2.8 & 21.4 & 6.6 & 2.45 & 3.9 & 75 & 45 & 6.5 \\
\hline \multicolumn{10}{|c|}{ between Ekspeditsii and Stupenchataya extrusions } \\
\hline B-2 a & 2.7 & 2.83 & 4.6 & 1.2 & 2.85 & 4.25 & 203 & 180 & 8.3 \\
\hline B-2 b & 2.51 & 2.83 & 11.3 & 1.6 & 2.8 & 4.3 & 128 & 118 & 6.1 \\
\hline B-2 c & 2.46 & 2.83 & 13.1 & 1.2 & 2.7 & 4.3 & 89 & 89 & 5.3 \\
\hline \multicolumn{10}{|c|}{ south of Booth of Volcanologists } \\
\hline B-18 a & 2.36 & 2.82 & 16.3 & 1.6 & 3 & 4.65 & 100 & 100 & 22.1 \\
\hline B-18 b & 2.31 & 2.82 & 18.1 & 1.6 & 3 & 4.5 & 73 & - & 22.1 \\
\hline B-18 c & 2.06 & 2.82 & 26.9 & 1.9 & 2.6 & 4 & 66 & 60 & 15.2 \\
\hline \multicolumn{10}{|c|}{ between Pestrye Khrebtiki and Lokhmatyi extrusive domes } \\
\hline B-19 a & 2.48 & 2.84 & 12.7 & 2.3 & 3.6 & 4.5 & 86 & 85 & 22.1 \\
\hline B-19b & 2.49 & 2.84 & 12.3 & 1.8 & 3.3 & 4.25 & 90 & - & 25.0 \\
\hline \multicolumn{10}{|c|}{ under Vysokaya extrusion } \\
\hline B-23 a & 2.23 & 2.71 & 17.7 & 4.8 & 1.75 & 2.75 & 75 & - & 35 \\
\hline B-23 b & 1.87 & 2.71 & 31.0 & 10 & 1.95 & 2.35 & 18 & 16 & 28.3 \\
\hline B-23 d & 1.49 & 2.71 & 45.0 & 22 & 1.95 & 1.95 & 35 & 23 & 10.8 \\
\hline
\end{tabular}


Table 3. (Contd.)

\begin{tabular}{|c|c|c|c|c|c|c|c|c|c|}
\hline Sample \# & $\rho \mathrm{g} / \mathrm{cm}^{3}$ & $\rho_{0} \mathrm{~g} / \mathrm{cm}^{3}$ & $n \%$ & $W \%$ & Vpd km/s & Vpw km/s & Rs MPa & Rsb MPa & ǽ $\cdot 10^{-3}$ SI units \\
\hline 1 & 2 & 3 & 4 & 5 & 6 & 7 & 8 & 9 & 10 \\
\hline \multicolumn{10}{|c|}{ near Pogrebennaya extrusion } \\
\hline B-25 a & 2.49 & 2.79 & 10.7 & 2.1 & 1.9 & 3.5 & 126 & - & 43.0 \\
\hline B- $25 b$ & 2.43 & 2.79 & 12.9 & - & 1.95 & - & 72 & - & 33.0 \\
\hline B-25 c & 2.09 & 2.79 & 25.1 & 5.5 & 2.25 & 3.5 & 56 & - & 15.5 \\
\hline B-25d & 2.4 & 2.79 & 14.0 & - & 2.0 & - & 80 & - & 20.5 \\
\hline B-25 e & 2.42 & 2.79 & 13.3 & - & 1.7 & - & 94 & - & 10.0 \\
\hline \multicolumn{10}{|c|}{ between Dvuglavaya and Gladkaya extrusions } \\
\hline B-27 a & 2.67 & 2.88 & 7.3 & 1.1 & 3.25 & 4.5 & 190 & - & 49.5 \\
\hline B-27 b & 2.45 & 2.88 & 14.9 & 1.8 & 2.95 & 4.2 & 140 & 99 & 42.9 \\
\hline B-27 c & 2.63 & 2.88 & 8.7 & 1.1 & 3.4 & 4.65 & 146 & - & 45.0 \\
\hline B-27 d & 2.63 & 2.88 & 8.7 & 0.3 & 3.15 & 4.45 & 166 & 103 & 45.0 \\
\hline \multicolumn{10}{|c|}{ in ravine between Bezymyannyi and Kamen' volcanoes } \\
\hline B-34 a & 2.51 & 2.82 & 11.0 & 0.7 & 2.5 & 4.45 & 125 & 87 & 33.3 \\
\hline B-34 b & 2.41 & 2.82 & 14.5 & 1.7 & 2.2 & 4.25 & 79 & 66 & 30.0 \\
\hline B-34 c & 2.26 & 2.82 & 19.9 & 3.7 & 2.3 & 3.9 & 50 & 43 & 40.0 \\
\hline B-34 c & 2.2 & 2.82 & 22.0 & - & 2.35 & - & 45 & - & 33.0 \\
\hline B-34 c & 2.1 & 2.82 & 25.5 & - & 2.2 & - & 23 & - & 33.0 \\
\hline B-35 & 2.6 & 2.82 & 7.8 & 1.1 & 2.9 & 4.3 & 151 & 118 & 27 \\
\hline B-36 & 2.31 & 2.82 & 18.1 & 3.9 & 2.8 & 4.35 & 67 & - & 41.6 \\
\hline \multicolumn{10}{|c|}{ lava flows on Novyi dome generated in 1981-1983 } \\
\hline $831012-1$ & 2.15 & 2.73 & 21.2 & - & 1.9 & 2.65 & 28 & - & 8.7 \\
\hline $831012-1$ a & 2.04 & 2.73 & 25.3 & - & 1.85 & 2.7 & 25 & 25 & 9.3 \\
\hline $831012-2$ & 2.1 & 2.73 & 23.1 & 7 & 1.9 & 2.3 & 56 & 42 & 10.7 \\
\hline $831012-3$ & 1.86 & 2.71 & 31.4 & 11 & 1.75 & 2.1 & 36 & 33 & 1.4 \\
\hline $831012-3 \mathrm{a}$ & 1.83 & 2.71 & 32.5 & - & 1.8 & 1.85 & 24 & 24 & 1.5 \\
\hline $831012-6$ & 1.88 & 2.73 & 31.1 & - & 1.8 & 2.3 & 29 & 26 & 5 \\
\hline $831012-6$ a & 1.83 & 2.73 & 33.0 & - & 1.8 & 2.15 & 22 & 22 & 5 \\
\hline $831012-7$ & 1.87 & 2.73 & 31.5 & - & 2.05 & 2.15 & 27 & 23 & 4.1 \\
\hline $831012-7 \mathrm{a}$ & 1.82 & 2.73 & 33.3 & - & 1.9 & - & 21 & - & 4.1 \\
\hline \multicolumn{10}{|c|}{ lava flows on Novyi dome generated in 1985-1989 } \\
\hline G-2889-2 sixth layer & 1.13 & 2.68 & 57.8 & 27.3 & 1.6 & 2.15 & 2.9 & - & 16 \\
\hline G-4389 fifth layer & 1.57 & 2.7 & 41.9 & 28.4 & 1.5 & - & 5.8 & - & 14 \\
\hline Po $186 \mathrm{D}$ fourth layer & 1.77 & 2.69 & 34.2 & 23.7 & 1.8 & 2.7 & 24.5 & - & 7.6 \\
\hline G-3589 A fourth layer & 1.92 & 2.68 & 28.4 & 17.7 & 1.65 & 2.5 & 39 & - & 30 \\
\hline G-3589 B third layer & 2.03 & 2.71 & 25.1 & 12.8 & 1.75 & 2.5 & 47 & - & 32 \\
\hline G-3889-3 third layer & 1.77 & 2.71 & 34.7 & 26.9 & 1.65 & 3.3 & - & - & - \\
\hline G-3889-2 third layer & 1.95 & 2.71 & 28.0 & 9.4 & 2.05 & - & - & - & 25 \\
\hline G-3889-1 third layer & 2.15 & 2.71 & 20.7 & 3.7 & 2.1 & 3 & 65 & - & 38 \\
\hline G-3289 second layer & 2.01 & 2.75 & 26.9 & 18.5 & 1.8 & 2.35 & 42.8 & - & 27 \\
\hline G-3389-3 first layer & 2.32 & 2.67 & 13.1 & 6.7 & 1.5 & 2.3 & 88 & - & 45 \\
\hline 99-84-2 first layer & 2.28 & 2.7 & 15.6 & 7.1 & 1.85 & 2.95 & 78.5 & - & 38 \\
\hline 17-85-3 first layer & 2.47 & 2.69 & 8.2 & 4.9 & 2.0 & 3.4 & 169 & - & 47 \\
\hline
\end{tabular}

Note: 831011-15 and 831011-16 are andesites with hornblende phenocrysts and a microlitic groundmass texture; 17-85-3 is andesite with some individual orange hornblende crystals. 
nyi (the others who also climbed onto the lava flow of the dome were I.A. Kondrashov and A.B. Belousov).

We provisionally identified six layers by sight in the flow volume from bottom to top:

(1) Whitish, light grey, dense andesite (G3389, 99-84, 17-85, 48-89);

(2) Grey, dense andesite (G3289);

(3) Grey, greenish, porous andesite (G3589B, G3989, G3889);

(4) Black, relatively dense andesite (Po186G, G3589A);

(5) Black, porous andesite (G4389);

(6) Grey, foamy andesite (G2889).

Since the flow is rather thick, viz., about $10 \mathrm{~m}$, the crystallization conditions were different in different parts of it; possibly the very generation of the flow was complex, giving rise to certain petrophysical peculiarities in some of its parts. Taken as a whole, the flow is composed of andesitic lavas with porphyry texture. The phenocrysts consist of plagioclase, frequently zonal, with glass inclusions; less often they consist of monoclinic and rhombic pyroxene. The groundmass is composed of the same minerals and of volcanic glass. The crystals are 0.5 to $2 \mathrm{~mm}$ across. The amount of phenocrysts varies between 10 and $25 \%$. Rhombic pyroxene phenocrysts are very rare and are much smaller than plagioclase and are between the phenocrysts of the latter and their microlites in the groundmass. The andesites occasionally contain glomerophyric intergrowths, with most of these consisting of plagioclase, but also occasionally containing some pyroxene (samples 3389 and 4389). The groundmass is composed of plagioclase microlites 0.1 to $0.5 \mathrm{~mm}$ across. The microlites are short-columnar with clear faces. The concentration of pyroxene is 5 to $20 \%$, both monoclinic and rhombic pyroxenes are present. The crystals of rhombic pyroxene are mostly elongate and appreciably less abundant. The monoclinic pyroxene has a more definite isometric shape. Occasionally pyroxene is oxidized at the edges and surrounded by a black strip (samples 4889, Po186, 4389). Volcanic glass is present in all samples, although the amount of it widely varies, from $5-20 \%$ to $30-50 \%$ (samples 1785, 4389, 3289). The glass has various colors, from white to light brownish (samples 3289, Po186, $3589,2889,1785$ ) to brown (sample 4389). As well, the glass has varying texture: there are quite transparent and homogeneous types, but one also encounters glass with multiple minute crystallites (samples 9984, 1785, 3289, 2889 ). In relation to the amount of volcanic glass the rock texture varies, from intersertal for most andesites to hyalopilitic (samples 4389, 1785). Sample 1785 contains individual crystals of orange hornblende up to 1 $\mathrm{mm}$ across, which is frequently fritted. Crystals with an opacite rim are not infrequently surrounded by small grains of ore minerals. The differences in mineral composition have produced some differences in the chemical composition of the rocks and in their properties (see Table 3).
We see a gradual diminution of the concentration of $\mathrm{SiO}_{2}$ from bottom to top of the flow by nearly $1.8 \mathrm{wt} \%$. The lowest concentration of $\mathrm{TiO}_{2}$ occurs in the middle of the flow (in the black andesite), with the value being smaller than in the top and bottom by a factor of nearly 2.7. The concentration of $\mathrm{Al}_{2} \mathrm{O}_{3}$ gradually increases by $1.2 \mathrm{wt} \%$ and then suddenly drops in the case of black andesites by $2.7 \mathrm{wt} \%$. The concentration of $\mathrm{MgO}$ is about the same for all andesites. The concentration of $\mathrm{CaO}$ is slightly higher in foamy andesites (in the top of the flow); the concentration of $\mathrm{Na}_{2} \mathrm{O}$ is somewhat higher in black andesites. The concentration of $\mathrm{K}_{2} \mathrm{O}$ is slightly lower in the foamy andesites compared with the other rocks.

There is a clear pattern of variation in the physical and physicomechanical properties of andesite from the bottom to top of the flow: the density changes from 2.47 to $1.13 \mathrm{~g} / \mathrm{cm}^{3}$, the porosity changes from 8.2 to $57.8 \%$, the strength changes from 169 to $2.9 \mathrm{MPa}$, and the magnetic susceptibility changes from $47 \cdot 10^{-3}$ to $16 \cdot 10^{-3}$ SI units (see Table 3 ). The quantity that remains practically the same (within the measurement error) is the density of the solid phase (2.68$2.71 \mathrm{~g} / \mathrm{cm}^{3}$ ), which also indicates a composition that is suitable for andesite. Certain patterns occur in the variation of the properties across the flow. The density decreases and the porosity increases from the lower part of the flow, which consists of dense andesites, toward the middle and further to the top, to foamy andesites. The rock properties that are directly related to porosity (water absorption and strength) have the same tendency to decrease from bottom to top (see Table 3). The correlative relationship of the average strength as a function of the average porosity for individual layers (from the first to the sixth) is well-pronounced and is given by the formula $y=378.52 \mathrm{e}^{-0.087 x}$ with a reliability coefficient of $\mathrm{R}^{2}=0.9636$ (Fig. 2).

One notices unusually low compressional velocities for air-dried andesites, which vary between 1.5 and $2.1 \mathrm{~km} / \mathrm{s}$ and are completely independent of density and porosity.

The highest magnetic susceptibility occurs in the andesites that are found in the lower parts of the flow.

\section{RESULTS AND DISCUSSION}

Our studies showed that of the eight isolated lava flows that were studied on the volcano's slopes (except for quite recent ones), six consist of basaltic andesites and two of hornblende andesites (see Table 2). Similar andesites also compose a mere 2 of the 15 flows found in the section of volcanogenic rocks in the wall of the 1956 Bezymyannyi explosion crater; this provides evidence that the effusive rocks of this volcano are dominated by basaltic andesites with phenocrysts that consist of plagioclase and pyroxene.

The diversity of the rocks, both as to mineral composition and textural features, indicates that the Bezymy- 
annyi volcanism is complex in character. The section of deposits in the Bezymyannyi somma encompasses the entire range of effusive rocks that are encountered around the volcano; this supports the hypothesis that the lava flows around the volcano were formed by eruptions of Bezymyannyi Volcano proper rather than being due to the numerous extrusions around it.

The mineral diversity in the phenocrysts provides evidence of the different thermodynamical conditions that obtained during the crystallization of melts; these different conditions caused changes both in the structures of the minerals that compose the rocks and in the junctions between minerals and, in all probability, gave rise to this diversity in lava properties.

One notes that the lowest values of physicomechanical properties occur in the andesites that contain hornblende phenocrysts. The basaltic andesites have higher values, with the phenocrysts consisting of plagioclase and pyroxene. The highest values of physicomechanical properties occur in those basaltic andesites with plagioclase phenocrysts. This is largely due to the greater homogeneity of the rock (the phenocrysts are no more than $1-3 \%$ of the total mass of the sample). The microlites consist of long, narrow, frequently oriented, plagioclase crystals. The concentration of pyroxene in the groundmass is up to $15 \%$; that of ore minerals is up to $3 \%$.

The rocks we have studied mostly have higher values of porosity owing to a high water content in magma melts. It was found that the lava flows contain nearly no massive varieties (with porosities of less than 5-7\%).

Very frequently the structure of the groundmass in effusive rocks (the relationships between its mineral components, i.e., plagioclase, pyroxene, and volcanic glass) is the controlling factor for the physicomechanical properties. The Bezymyannyi basaltic andesites have hyalopilitic, intersertal, and microlitic textures of the groundmass, with the latter being rare. It was found that the properties of these principal varieties of the volcano's rocks are similar (Tables 4 and 5), which is probably to be attributed to their high porosity which masks the effects of texture, even though the rocks with hyalo-

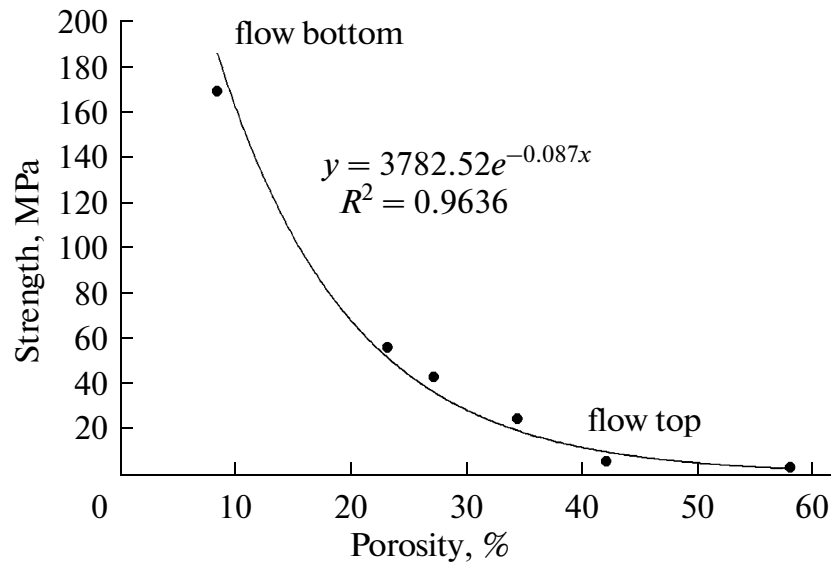

Fig. 2. The variation in the average strength and porosity from the bottom to top for the Bezymyannyi recent lava flows, in particular, those generated in 1986-1989.

pilitic texture compose much fewer lavas with densities of over $2.5 \mathrm{~g} / \mathrm{cm}^{3}$ ( 6 of 35 samples) compared with the effusive rocks with intersertal texture (16 of 36 samples). We found a well-defined pattern in the relationship of uniaxial compressive strength to density in lavas, with the relationship being fairly well described by an exponential curve (Fig. 3). The strength is the same for the rocks with intersertal and hyalopilitic textures and is given by the formula $y=0.3184 \mathrm{e}^{2.3652 x}$ with a reliability coefficient of $\mathrm{R}^{2}=0.8865$.

The ranges of variation for the petrophysical properties of the Bezymyannyi effusive rocks are as follows: the density is between 1.13 and $2.78 \mathrm{~g} / \mathrm{cm}^{3}$; however, most of the density values (nearly $70 \%$ ) are in the range between 2.3 and $2.7 \mathrm{~g} / \mathrm{cm}^{3}$. The lava uniaxial compressive strength varies within two orders of magnitude, from 2.9 to $221 \mathrm{MPa}$; compressional velocities are contained within the limits $1.5 \mathrm{~km} / \mathrm{s}$ and $4.4 \mathrm{~km} / \mathrm{s}$; and the magnetic susceptibility varies from 1.4 to $57.7 \cdot 10^{-3}$ SI units.

It should be noted that compressional velocities in most of the volcanic rocks that were studied are low.

Table 4. The average values of physicomechanical properties in the Bezymyannyi lava flows with different kinds of phenocrysts

\begin{tabular}{l|c|c|c|c|c|c|c|c|c}
\hline \multicolumn{1}{c|}{ Phenocrysts in lavas } & $\rho \mathrm{g} / \mathrm{cm}^{3}$ & $\rho_{0} \mathrm{~g} / \mathrm{cm}^{3}$ & $n \%$ & $W \%$ & Vpd km/s & Vpw km/s & Rs MPa & Rsb MPa & $\cdot 10^{-3}$ SI units \\
\hline hoernblende (10) & 2.23 & 2.76 & 19.0 & - & 1.9 & 2.85 & 77.5 & 60 & 7.2 \\
plagioclase and pyroxene (24) & 2.42 & 2.81 & 13.8 & 2.1 & 2.8 & 4.2 & 106 & 89 & 7.5 \\
orthopyroxene and clinopy- & 2.54 & 2.86 & 10.9 & 1.4 & 2.85 & 4.3 & 142 & 126 & 7.4 \\
roxene (9) & 2.59 & 2.88 & 9.9 & 1.1 & 3.2 & 4.45 & 160 & 101 & 14.0 \\
Plagioclase (4) & & & & & & & \\
\hline
\end{tabular}

Note: The figures in parentheses indicate the number of samples. 
Table 5. The average values of physicomechanical properties in the rocks of the Bezymyannyi lava flows with different groundmass textures

\begin{tabular}{l|c|c|c|c|c|c}
\hline Lava groundmass texture & $\rho \mathrm{g} / \mathrm{cm}^{3}$ & $\rho_{0} \mathrm{~g} / \mathrm{cm}^{3}$ & $n \%$ & Vpw km/s & Rs MPa & ǽ $10^{-3}$ SI units \\
\hline intersertal & 2.38 & 2.78 & 14.4 & 2.5 & 109 & 7.4 \\
hyalopilitic & 2.30 & 2.81 & 13.9 & 2.45 & 81 & 8.0 \\
\hline
\end{tabular}

This corroborates the inference made by Ladygin and Nikitin [1989] concerning the unusually low velocities in Upper Quaternary to Holocene effusive rocks. This phenomenon was previously noted for lavas that were discharged by Avacha, Mutnovskii, Klyuchevskoi and several other volcanoes and results from microcracking in young effusive rocks, which is in turn due to the conditions under which these rocks cooled and crystallized [Ladygin and Nikitin, 1980].

One other feature that is peculiar to the Bezymyannyi lavas is the fact that the lowest values of magnetic susceptibility occur in the recent lava flows while the highest values occur in the oldest flows.

The following pattern was observed: the older a lava flow is, the higher the parameters of the constituent rocks are. There is an explanation for this. Judging from the modern lava flows of Bezymyannyi Volcano that have been discharged since 1977, the structure of these flows is zonal, with the porosity increasing from bottom to top of a lava flow, even to reach the degree of foam. It has been repeatedly pointed out that explosive eruptions of Bezymyannyi produce partial destruction and collapse of the upper "porous layers" (or zones) in lava

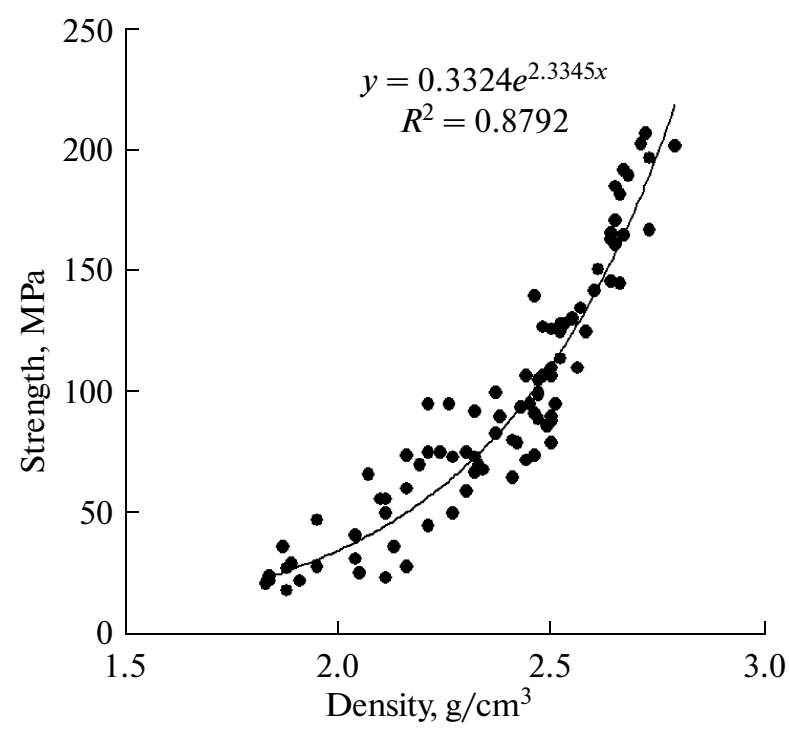

Fig. 3. Strength as a function of density for all the rocks that were found in the Bezymyannyi lava flows. flows over which pyroclastic flows were descending [Girina et al., 1993; Girina and Gorbach, 2006]. That is to say, the older a lava flow is, the thinner the "porous layer" at the top of the flow is. The oldest flows probably consist only of the lower dense lava layer, with the other zones (the foamy one in the first place) being destroyed as time passed (by subsequent eruptions or by weathering processes) and now composing clastic rock sequences, thus inflating the portion of volcanoclastic rocks in the older rock sequences.

\section{CONCLUSIONS}

(1) The geological section of Bezymyannyi Volcano encompasses the entire range of individual effusive rocks to be found around it, thus leading us to believe that the lava flows studied here were formed by eruptions of Bezymyannyi Volcano proper.

(2) The petrographic compositions of the rocks found in the lava flows are rather diverse, ranging from hornblende pyroxene to bipyroxene basaltic andesite, thus providing evidence that the volcano discharged magma melts with different compositions. Most of the lava flows studied here consist of basaltic andesites.

(3) Nearly all the andesites and basaltic andesites studied here are highly porous, indicating a high gas content in the magma melts. No massive rock varieties with low porosities have been found.

(4) The rocks we studied have low compressional velocities, whatever their texture and porosity, which is typical of Upper Quaternary to Holocene effusive rocks.

(5) It is supposed that the upper parts of the lava flows, those with the highest porosity, decay comparatively rapidly and thus increase the portion of clastic volcanogenic material. For this reason, the oldest lava flows only consist of their lower parts (the bottom), as being the most resistant rocks that have not experienced destruction. This should be remembered in paleovolcanological research.

\section{REFERENCES}

Alidibirov, M.A., Bogoyavlenskaya, G.E., Kirsanov, I.T., et al., The 1985 Eruption of Bezymyannyi Volcano, Vulkanol. Seismol., 1988, no. 6, pp. 3-17. 
Almeev, R.R., Kimura, J.-I., Ozerov, A.A., et al., Geochemistry of Bezymianny Volcano Lavas: Signatures of a Mantle Precursor and Magma Fractionation, Geophys. Res. Abstr., 2004, vol. 6, 04913.

Alypova, O.M., Some Evidence for Physical Properties of Volcanic Rocks in the Klyuchevskoi Volcanic Cluster Area, Byul. Vulkanol. St., 1967, no. 43, pp. 56-62.

Bogoyavlenskaya, G.E. and Kirsanov, I.T., The Twenty Five Years of Volcanic Activity: Bezymyannyi Volcano, Vulkanol. Seismol., 1981, no. 2, pp. 3-13.

Bogoyavlenskaya, G.E., Braitseva, O.A., Melekestsev, I.V., et al., Bezymyannyi Volcano, in Deistvuyushchie vulkany Kamchatki (Active Volcanoes of Kamchatka), vol. 1, Moscow: Nauka, 1991, pp. 168-194.

Bogoyavlenskaya, G.E., Naumov, V.B., Tolstykh, M.L., et al., Melt Compositions and the Crystallization Conditions for Andesites from Avacha, Bezymyannyi, Shiveluch, and Karymskii Volcanoes: A Study of Molten Inclusions, Vulkanol. Seismol., 2004, no. 6, pp. 35-48.

Braitseva, O.A. and Kir'yanov, V.Yu., On the Past Activity of Bezymyannyi Volcano Based on Data of Tephrochronologic Studies, Vulkanol. Seismol., 1982, no. 6, pp. 44-55.

Braitseva, O.A., Melekestsev, I.V., Bogoyavlenskaya, G.E., and Maksimov, A.P., Bezymyannyi: Eruptive History and Dynamics, Vulkanol. Seismol., 1990, no. 2, pp. 3-32[Volcanology and Seismology, 1991, vol. 12, no. 2, pp. 165-194, Gordon and Breach Science Publishers].

Girina, O.A., Piroklasticheskie otlozheniya sovremennykh andezitovykh vulkanov Kamchatki $i$ ikh inzhenerno-geologicheskie osobennosti (The Pyroclastic Deposits of Contemporary Andesitic Volcanoes in Kamchatka and their Engineering-Geological Features), Vladivostok: Dal'nauka, 1998.

Girina, O.A., Bogoyavlenskaya, G.E., and Demyanchuk, Yu.V., Bezymyannyi Eruption of August 2, 1989 , Vulkanol. Seismol., 1993, no. 2, pp. 8-16 [Volcanology and Seismology, 1993, vol. 15, no. 2, pp. 135-144, Gordon and Breach Science Publishers].

Girina, O.A. and Gorbach, N.V., The January 11, 2005 Eruption of Bezymyannyi Volcano, in Problemy eksplozivnogo vulkanizma ( $k$ 50-letiyu katastroficheskogo izverzheniya vulkana Bezymyannyi) (Problems in Explosive Volcanism: 50 years since a Catastrophic Eruption of Bezymyannyi Volcano), Proc. Intern. Symp., PetropavlovskKamchatskii: IViS DVO RAN, 2006, pp. 87-97.

Gorshkov, G.S., and Bogoyavlenskaya, G.E., Vulkan Bezymyanny i osobennosti ego poslednego izverzheniya (Bezymyannyi Volcano and Its Last Eruptions in 1955-1963). Moscow: Nauka, 1965.

Kadik, A.A., Maksimov, A.P., and Ivanov, B.V., Fizikokhimicheskie usloviya kristallizatsii $i$ genezis andezitov (na primere Klyuchevskoi gruppy vulkanov) (Physicochemical Conditions of Crystallization and the Origin of Andesites: The Klyuchevskoi Group of Volcanoes), Moscow: Nauka, 1986.
Kirsanov, I.T., Extrusive Eruptions on Bezymyannyi Volcano in 1965-1974 and Their Geological Effects, in Problemy glubinnogo magmatizma (Problems of Deep-Seated Magmatism), Moscow: Nauka, 1979, pp. 50-69.

Kozyrev, A.I., Klyuchevskoi Lava Density Measurements, Vulkanol. Seismol., 1990, no. 1, pp. 65-75 [Volcanology and Seismology, 1991, vol. 12, no. 1, pp. 99-115, Gordon and Breach Science Publishers].

Kozyrev, A.I., Farberov, A.I., and Vande-Kirkov, Yu.V., The Physical Properties of Lavas and Hypabyssal Intrusions from Avacha and Koryakskii Volcanoes, Vulkanol. Seismol., 1989, no. 6, pp. 54-72 [Volcanology and Seismology, 1991, vol. 11, no. 6, pp. 829-855, Gordon and Breach Science Publishers].

Ladygin, V.M. and Nikitin, V.N., On Some Features in the Properties of Young Effusive Rocks in Kamchatka, Vestnik $M G U$, ser. 4, Geologiya, 1980, no. 5, pp. 81-86.

Ladygin, V.M. and Okrugin, V.M., Petrophysical Properties of Basalts Discharged during the Great Tolbachik Fissure Eruption, Vestnik MGU, ser. 4, Geologiya, 1998, no. 3, pp. 45-49.

Ladygin, V.M. and Frolova, Yu.V., Petrophysical Properties of Effusive Rocks of Klyuchevskoi Volcano, Vulkanol. Seismol., 2002, no. 3, pp. 11-27.

Ladygin, V.M., Girina, O.A., Frolova, Yu.V., and Kondrashov, I.A., The Lava Flows of Bezymyannyi Volcano, Kamchatka, in Materialy 4-go mezhdunarodnogo soveshchaniya po protsessam v zonakh subduktsii Yaponskoi, KuriloKamchatkaskoi i Aleutskoi ostrovnykh dug (JKASP) (Proc. 4th International Conf. on Japan-Kamchatka-Alaska Subduction Processes, JKASP), Petropavlovsk-Kamchatskii: IViS DVO Russian Academy of Sciences, 2004, pp. 62-63.

Ladygin, V.M. and Frolova, Yu.V., Using Petrophysical Studies to Deal with Volcanological Problems, in III Vserossiiskii simpozium po vulkanologii i paleovulkanologii (The 3rd AllRussia Symp. on Volcanology and Paleovolcanology), UlanUde: BNTs SO Russian Academy of Sciences, 2006, vol. 1, pp. $42-46$.

Maksimov, A.P., Firstov, P.P., Girina, O.A., and Malyshev, A.I., The June 1986 Eruption of Bezymyannyi, Vulkanol. Seismol., 1991, no. 1, pp. 3-20 [Volcanology and Seismology, 1992, vol. 13, no. 1, pp. 1-20].

Malyshev, A.I., Zhizn'vulkana (The Life of Volcanoes), Yekaterinburg: UrO RAN, 2000.

Ozerov, A.Yu., Ariskin, A.A., Kail, F., et al., A PetrologicGeochemical Model for the Genetic Affinity between Basaltic and Andesitic Volcanisms: Klyuchevskoi and Bezymyannyi Volcanoes, Kamchatka, Petrologiya, 1997, vol. 5, no. 6, pp. 614-635.

Tolstykh, M.L., Naumov, V.B., Bogoyavlenskaya, G.E., and Kononkova, N.N., Andesite-Dacite-Rhyolite Melts during Crystallization of Andesitic Impregnations: Bezymyannyi Volcano, Kamchatka, Geokhimiya, 1999, no. 1, pp. 14-24. 